\title{
Analisis Pendapatan Regional Kawasan Ekonomi Khusus Wilayah Papua Barat
}

\author{
Rully N. Wurarah ${ }^{1}$, Sarce B. Awom ${ }^{2}$ \\ ${ }^{1,2}$ Dosen Program Studi Ekonomi Pembangunan, Universitas Papua
}

Received: Juli 2020; Accepted: Agustus 2020; Published: September 2020

\begin{abstract}
Abstrak
Kawasan Ekonomi Khusus (KEK) merupakan salah satu pendorong aktivitas ekonomi yang ditunjang oleh berbagai kegiatan investasi. Pengembangan KEK Kota Sorong ditandai dengan makin bertambahnya minat investor melakukan pengembangan usahanya, baik pada sektor industri yang memberikan dampak terhadap pembentukan nilai tambah berupa peningkatan pendapatan dan output PDRB, maupun pada sektor ekonomi lainnya. Data primer bersumber dari informan kunci pada OPD Bappeda di Kabupaten Sorong, Kabupaten Raja Ampat dan Kota Sorong, sedangkan data sekunder bersumber dari laporan BPS dan Bappeda. Analsisi terhadap data yang dikumpulkan dilakukan secara deskriptif dan tabulasi untuk melihat perubahan pendapatan selama 5 tahun terakhir. Hasil yang diperoleh menunjukan bahwa terjadi peningkatan perolahan pendapatan pada masingmasing wilayah (Kabupaten Sorong, Kabupaten Raja Ampat dan Kota Sorong). Perolehan pendapatan perkapita Kota Sorong yang lebih dominan menunjukan bahwa nilai tambah sektor jasa lebih kompetitif dibandingkan dengan sektor lainnnya. Berkembangnya Kota Sosong sebagai sentral KEK telah mendorong berkembangnya Kabupaten Sorong dan Kabupaten Raja Ampat, sehingga yang perlu diperhatikan bahwa kedua Kabupaten tersebut harus dapat mendorong faktor produksi yang menjadi input pada pengembangan Kota Sorong. Faktor penting yang harus diperhatikan dalam pengembangan KEK Sorong adalah peningkatan kapasistas penduduk sebagai faktor produksi dan pengembangan industri rumah tangga yang memanfaatkan bahan baku lokal dalam menunjang sektor sektor unggulan yang berada pada masing-masing wilayah pada KEK Sorong, sehingga dapat memacu peningkatan pendapatan masyarakat.
\end{abstract}

Kata kunci: kawasan ekonomi khusus, pendapatan regional, produksi

\begin{abstract}
Special Economic Zones (SEZ) are one of the drivers of economic activity supported by various investment activities. The development of Sorong City SEZ is marked by the increasing interest of investors in developing their businesses, both in the industrial sector which has an impact on the formation of added value in the form of increased income and output of the GRDP, as well as in other economic sectors. Primary data were sourced from key informants in Bappeda OPD in Sorong Regency, Raja Ampat Regency and Sorong City, while secondary data were sourced from BPS and Bappeda reports. The analysis of the data collected was done descriptively and tabulated to see changes in income over the past 5 years. The results obtained indicate that there has been an increase in income planning in each region (Sorong Regency, Raja Ampat Regency and Sorong City). Sorong City per capita income which is more dominant shows that the added value of the service sector is more competitive compared to other sectors. The development of Sosong City as a central KEK has encouraged the development of Sorong Regency and Raja Ampat Regency, so that it is important to note that the two regencies must be able to encourage the production factors which become inputs to the development of Sorong City. An important factor that must be considered in the development of the SEZ is the increase in population capacity as a factor of production and the development of home industries that utilize local raw materials to support the leading sectors in each region of the SEZ, so as to spur an increase in public income.
\end{abstract}

Keywords: special economic zones, regional income, production 
How to Cite: Wurarah, Rully N. \& Awom, Sarce B. (2020). Analisis Pendapatan Regional Kawasan Ekonomi Khusus Wilayah Papua Barat. JFRES: Journal of Fiscal and Regional Economy Studies, 3(2), 1 10

\section{PENDAHULUAN}

Pembangunan Kawasan Ekonomi Khusus (KEK) merupakan salah satu strategi dalam mendorong investasi di suatu daerah, sehingga dukungan kebijakan di perlukan untuk memenuhi persyaratan pembangunan KEK. Investasi yang berkembang dapat mendorong pertumbuhan ekonomi suatu daerah yang memberi dampak pada peningkatan lapangan pekerjaan dan penurunan jumlah penduduk miskin.

Pengembangan KEK dilakukan pada kawasan yang memiliki keunggulan geoekonomi dan geostrategi sehingga dapat berfungsi untuk menampung kegiatan industri, ekspor, impor, dan kegiatan ekonomi lain yang memiliki nilai ekonomi tinggi dan daya saing internasional. Mengembangkan kemampuan dan dayasaing ekonomi pada level nasional dapat melalui akselerasi sektor industri dan hingga tahun 2020 terdapat 15 KEK di Indonesia.

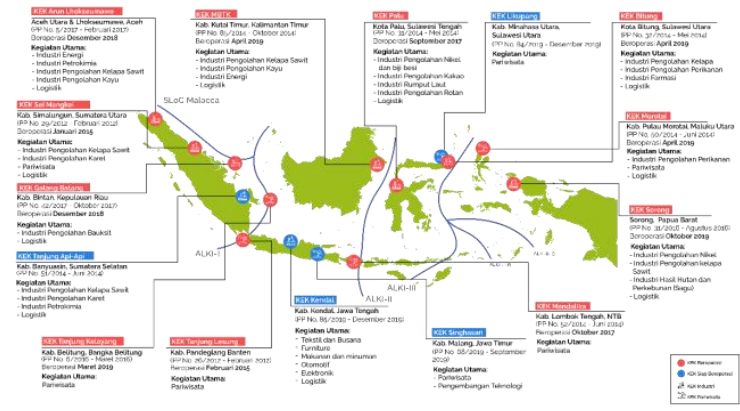

\section{Sumber : https://kek.go.id/peta-sebaran-kek}

Gambar 1. Peta Sebaran Kawasan Ekonomi Khusus di Indonesia

Melalui Peraturan Pemerintah Nomor 31 tahun 2016 Kota Sorong telah ditetapkan sebagai Kawasan Ekonomi Khusus (KEK) pertama di wilayah Papua. Penetapan KEK ini secara konseptual diharapkan dapat menjadi pusat pertumbuhan ekonomi baru di Kawasan Indonesia Timur yang sejalan dengan prinsip Nawacita yakni membangun Indonesia dari pinggiran. Secara strategis kawasan ini berada pada jalur lintasan perdagangan internasional
Asia Pasifik dan Australia pada lahan seluas 523,7 ha, yang terpusat di Selat Sele sehingga dapat memberikan keunggulan geoekonomi dengan potensi pada sektor perikanan dan perhubungan laut. Selain ini berpotensi juga untuk pengembangan industri logistik, agroindustri serta pertambangan.

Pengembangan KEK tersebut berbasis pada kegiatan industri galangan kapal, agroindustri, industri pertambangan dan logistik sehingga di proyeksikan menarik investor dengan nilai investasi sebesar Rp. 32,2 T dan penyerapan tenaga kerja sebanyak 15.025 tenaga kerja hingga tahun 2025. KEK Sorong ini meliputi Kabupaten Sorong, Kota Sorong dan kota baru Aimas dengan luas kawasan mencapai $6.000 \mathrm{Ha}$ di Arar Distrik Mayamuk dan 3.000 Ha di Seget Distrik Salawati, dan telah resmi beroperasi sejak tanggal 11 Oktober 2019.

Dampak positif dengan adanya KEK seperti yang dijelaskan oleh Sihaloho \& Muna (2016) yakni terjadi peningkatan ekspor, peningkatan penanaman modal asing, pertumbuhan industri, diversifikasi produksi, penciptaan lapangan kerja, dan meningkatnya kualitas SDM melalui peningkatan keahlian dan transfer teknologi. Dampak negatif dapat berupa biaya sosial seperti transfer sumber daya, akuisisi lahan, hilangnya lahan pertanian dan kemungkinan terjadinya disparitas ekonomi regional.

Todaro \& Smith (2011) menekankan bahwa terjadinya proses kemajuan dan perbaikan yang terus-menerus menuju tujuan yang diinginkan dapat dilihat dari peningkatan dan pemerataan kesejahteraan masyarakat. Meningkatnya kesejahteraan masyarakat merupakan salah satu tujuan dari pembangunan nasional yang harus didukung dengan berbagai kebijakan. Pembahasan Glinskiy et al. (2020) menekankan bahwa diferensiasi sistem sosial dan ekonomi menjadi dasar dalam memfasilitasi pembangunan secara umum sehingga dayasaing suatu daerah akan lebih spesifik walaupun terdapat beberapa 
masalah kebijakan berkaitan dengan pemerataan pembangunan yang efektif. Selanjutnya Aminudin et al. (2014) mengatakan bahwa terjadinya aliran capital dari wilayah yang kurang maju ke wilayah yan g lebih maju memberi dampak pada kesenjangan antara wilayah yang mengakibatkan terjadi konflik antara daerah.

Diferensiasi yang terjadi dalam masyarakat merupakan bentuk kondisi dari variasi dalam masyarakat baik dalam pekerjaan, kelompok maupun prestise yang dimiliki oleh sekelompok masyarakat. Melalui deferensiasi ini akan dapat dilihat hubungan antara tingkat pendapatan perkapita dengan Produk Domestik Reginoal Bruto (PDRB). Wurarah \& Bauw (2018) PDRB per kapita adalah rata-rata pendapatan yang diterima oleh setiap penduduk di suatu wilayah selama satu tahun yang dapat menunjukkan indikator untuk menggambarkan tingkat kemakmuran masyarakat secara makro.Semakin tinggi pendapatan yang diterima penduduk di suatu wilayah maka tingkat kesejahteraan di wilayah yang bersangkutan dapat dikatakan bertambah baik. PDRB per kapita diperoleh dengan cara membagi PDRB dengan jumlah penduduk pertengahan tahun.

Mengacu pada konsep yang dikembangkan Harrod (1939) dan Domar (1946) menunjukkan bahwa hasil yang diperoleh dari penggunaan seluruh faktor produksi dalam menghasilkan barang dan jasa dikatakan sebagai output. Sementara Domar mengembangkan gagasan tentang peran pengeluaran untuk investasi, yang dalam teori pertumbuhan ekonomi dijelaskan bahwa investasi meningkatkan kapasitas ekonomi. Karenanya dalam Thong \& Hao (2019) dijelaskan bahwa tingkat pertumbuhan ekonomi tergantung pada total tabungan dan hubungan antara modal dan output.

Investasi domestik secara fisik dicerminkan oleh jumlah Pembentukan Modal Tetap Bruto (PMTB) yang direalisasikan dalam satu tahun tertentu. Pendekatan perhitungan investasi melalui konsepsi tersebut disebut juga sebagai pendekatan arus barang baik menurut sektor maupun menurut institusi pelaku usaha. (Setiyanto, 2015). Melalui Teori pertumbuhan wilayah yang menganalisis suatu wilayah sebagai suatu sistem ekonomi terbuka berhubungan dengan wilayah-wilayah lain melalui arus perpindahan faktor-faktor produksi dan pertukaran komoditas. Pembangunan dalam suatu wilayah akan mempengaruhi pertumbuhan wilayah lain dalam bentuk permintaan sektor untuk wilayah lain yang akan mendorong pembangunan wilayah tersebut atau suatu pembangunan ekonomi dari wilayah lain akan mengurangi tingkat kegiatan ekonomi di suatu wilayah.

Berdasarkan hasil penelitian yang dilakukan oleh Makalew et al.(2019) menunjukkan bahwa sektor industri menengah memiliki nilai tambah terbesar dari output daerah sehingga perusahaan yang berada di industri menengah di kawasan ekonomi khusus telah memberikan multiplier effect bagi peningkatan pertumbuhan ekonomi, terutama pada peningkatan penyerapan tenaga kerja, dan peningkatan kontribusi sektor industri. Sektor industri ini dianggap mampu untuk mendongkrak sektor-sektor lainnya dalam meningkatkan pertumbuhan ekonomi suatu daerah seperti pada Kawasan Ekonomi Khusus Bitung dengan core business industri pengolahan perikanan, industri pengolahan kelapa, industri farmasi dan logistik telah menarik kegiatan investasi dan membuka lapangan pekerjaan

Pengalaman KEK di India, diawali dengan kegiatan promosi, investasi, dan pengembangan potensi kerja, serta ekspor yang tinggi telah memberikan keuntungan yang besar bagi pihak swasta. (K. P. Bholane, 2019). Studi yang dilakukan oleh Govindan (2019) menyimpulkan bahwa zona ekonomi khusus (KEK) telah memberikan kontribusi yang signifikan di masa lalu dengan cara investasi, investasi tambahan, pekerjaan dan lapangan kerja tambahan. Pertumbuhan dalam ekspor pada KEK di India mencapai lebih dari dua puluh lima persen dari total ekspor negara. Sektor teknologi informasi, sektor perangkat keras dan peralatan telekomunikasi telah mendominasi pencapaian output dari KEK di India.

Berdasarkan hasil penelitian yang dilakukan oleh Shanti Darmastuti, Afrimadona (2018) menyatakan bahwa secara umum terdapat 8 isu dan tantangan dalam pengembangan KEK yaitu: 1) struktur kelembagaan; 2) koordinasi antar lembaga; 3) sistem insentif dan regulasi pendukung; 4) keterbatasan pembangunan infrastruktur ; 5) lokasi dan aglomerasi dalam penentuan lokasi KEK yang kurang diperhitungkan; 6) belum optimalnya akses ke pasar domestik maupun internasional; 7) kesesuaian tenaga kerja yang tersedia. Selanjutnya Medina-Moral \& Montes-Gan (2018) menjelaskan bahwa terdapat pengaruh 
yang tidak dapat di duga bisa muncul yang di sebabkan oleh perbedaan teknologi maupun inovasi yang tersedia sehinga mempengaruhi akan output wilayah atau Produk Domestik Regional Bruto. Peningkatan output tersebut dari tahun ketahun disebabkan adanya peningkatan nilai tambah dari masing-masing sektor ekonomi.

Keberhasilan KEK di Negara India dan Cina terhadap pembangunan ekonomi ditandai dengan kegiatan investasi yang meningkat. Kondisi serupa terjadi di Provinsi Sulawesi Utara yang telah menarik investor sehingga mendorong pertumbuhan ekonomi. Dewan Nasional Kawasan Ekonomi Khusus (https://kek.go.id/ sorong) merinci peluang investasi pada KEK Sorong melalui: zona logistik seperti, pergudangan, trade center, open storage yard, fuel station, instalasi pengolahan air bersih, instalasi pengolahan air limbah, publik transport station; zona industri seperti industri pengolahan kelapa sawit dan industri pengolahan sagu; zona pengolahan ekspor seperti petrokimia, kilang minyak dan pembangkit listrik. Sektor ekonomi yang berada pada zona tersebut yang berpotensi memiliki daya dorong yang kuat untuk meningkatkan investasi dan menghasilkan produk barang dan jasa pada kawasan tersebut.

Produk barang dan jasa sebagai hasil dari aktivitas ekonomi disuatu wilayah tanpa memperhatikan apakah faktor produksinya berasal atau dimiliki oleh penduduk di wilayah tersebut merupakan Produk Domestik Regional Bruto (PDRB). Pendapatan yang timbul oleh karena kegiatan produksi tersebut merupakan pendapatan regional. Dengan memperhatikan akan pengalaman dan keberhasilan meningkatkan PDRB pada beberapa wilayah kawasan KEK maka perlu di analisis pendapatan regional pada KEK yang ada di Provinsi Papua Barat sehingga akan dapat memberikan masukan arah kebijakan dan pengembangan bagi perekonomian daerah.

\section{METODOLOGI}

Penelitian ini menggunakan metoda deskriptif kualitatif dengan lokasi penelitian adalah Kabupaten Sorong, Kabupaten Raja Ampat dan Kota Sorong. Ketiga wilayah kabupaten tersebut merupakan bagian dari Kawasan Ekonomi Khusus Sorong di Provinsi Papua Barat. Penelitian ini menggunakan data sekunder yang diperoleh dari instansi terkait seperti BPS, Badan Pengelolaan Keuangan Daerah, Bappeda pada setiap lokasi KEK Provinsi Papua Barat kurun waktu 2014 sampai dengan 2018. Selain itu diperoleh juga data primer, data yang diperoleh dari sumbernya melalui survei (studi lapangan) dilakukan dengan teknik wawancara semi struktural pada pihak-pihak yang terkait dengan studi, observasi, dan studi dokumentasi. Analsis data terhadap data yang dikumpulkan dilakukan secara deskriptif dan tabulasi untuk melihat perubahan pendapatan selama 5 tahun terakhir.
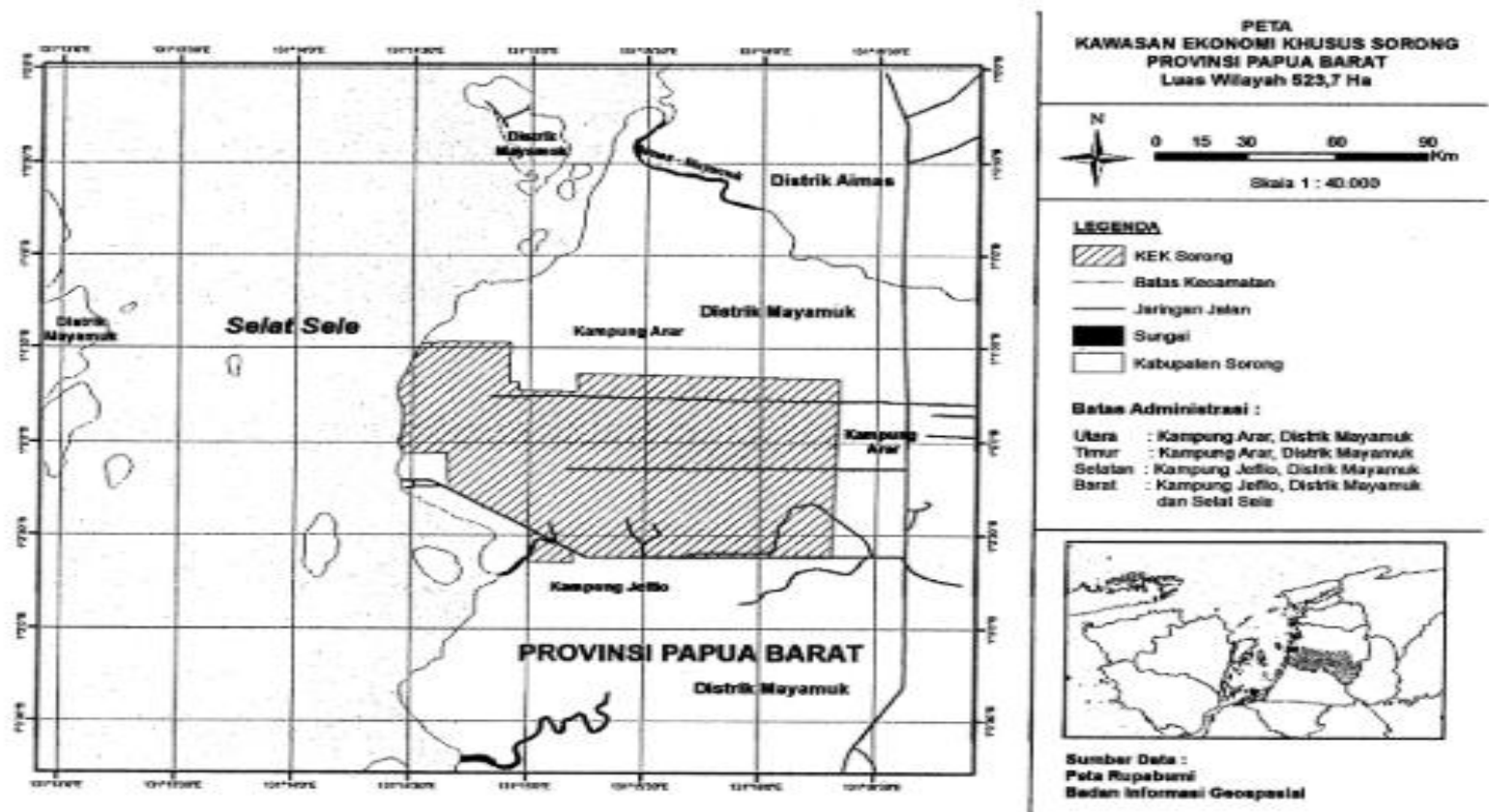

Sumber: Peraturan Pemerintah Republik Indonesia Nomor 31 Tahun 2016

Gambar 2. Peta Kawasan Ekonomi Khusus Sorong Provinsi Papua Barat 


\section{HASIL DAN PEMBAHASAN}

Secara konseptual sasaran Pengembangan Kawasan Ekonomi Khusus secara umum dimaksudkan untuk menarik investor sehingga terjadi peningkatan penanaman modal melalui penyiapan kawasan yang memiliki keunggulan geoekonomi dan geostrategis sehingga dapat mengoptimalkan aktivitas industri, ekspor, impor, dan kegiatan ekonomi lain yang memiliki nilai ekonomi tinggi. Upaya ini dapat mempercepat perkembangan daerah melalui pengembangan pusat-pusat pertumbuhan ekonomi baru sehingga terwujud terobosan pengembangan kawasan untuk pertumbuhan ekonomi, antara lain melalui sektor industri, pariwisata dan perdagangan sehingga dapat menciptakan lapangan pekerjaan.

Kawasan Ekonomi Khusus Sorong sebagaimana dimaksud terdiri dari zona Industri, zona logistik dan pengolahan ekspor dan dalam Lampiran Peraturan Pemerintah Republik Indonesia Nomor 31 Tahun 2016 Tentang Kawasan Ekonomi Khusus Sorong dijelaskan Peta Kawasan
Ekonomi Khusus Sorong Provinsi Papua Barat dengan luas wilayah 523,7 ha seperti ditampilkan pada Gambar 2.

Pertumbuhan pendapatan daerah Kota Sorong dan Kabupaten Sorong cenderung mengalami penurunan yang cukup signifikan pada tahun 2017. Namun pada tahun 2018 pertumbuhan pendapatan daerah mengalami perbaikan dengan pertumbuhan sebesar 64.58 dan 49.52 persen. Penurunan yang cukup drastis pada Kota Sorong terjadi pada tahun 2017, dimana pada tahun 2016 pendapatan daerah dari Rp1,818 milliar turun menjadi Rp885 milliar. Sedangkan pada Kabupaten Sorong dari Rp 1,429 milliar turun menjadi Rp 948 milliar. Penurunan ini disebabkan porsi pendapatan asli daerah dalam hal ini pos Hasil Pengelolaan Kekayaan Daerah yang Dipisahkan mengalami penurunan. Untuk Kabupaten Raja Ampat mengalami penurunan sebesar 11.60 persen pada tahun 2018, yakni dari Rp1,301 milliar menjadi Rp1,150 milliar. Selanjutnya untuk pendapatan Provinsi Papua Barat mengalami peningkatan cenderung mengalami peningkatan.

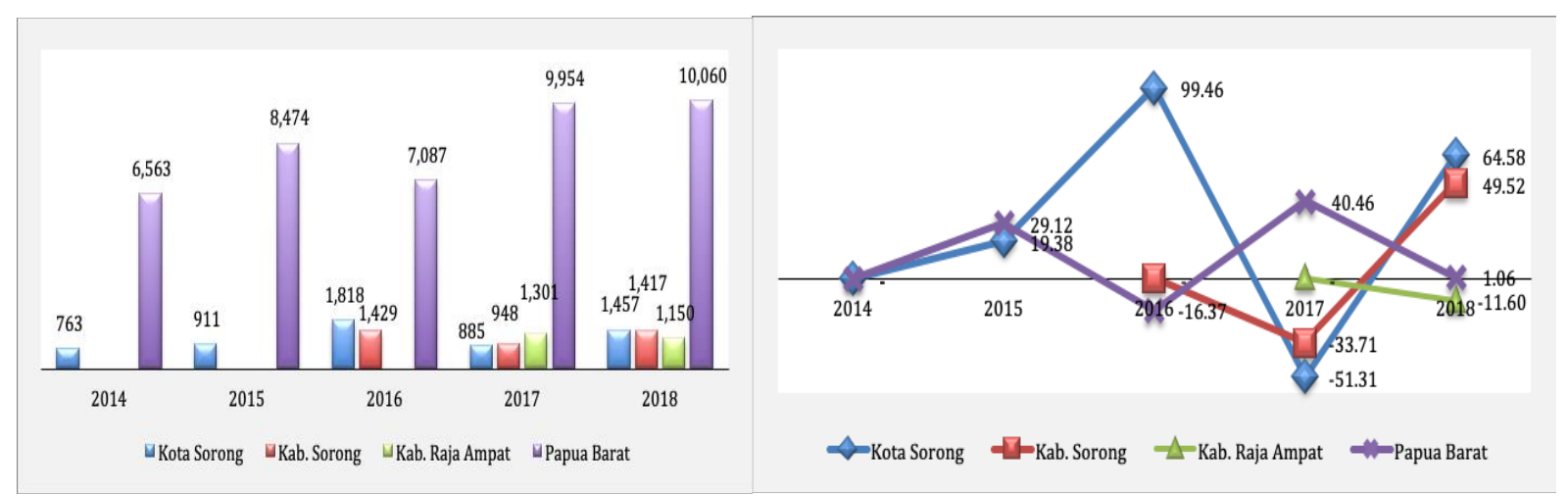

Sumber: APBD Kota Sorong, Kab. Sorong \& Kab. Raja Ampat, 2014 - 2018 (Data diolah)

Gambar 3. Total dan Pertumbuhan Pendapatan Rill, 2014 - 2018

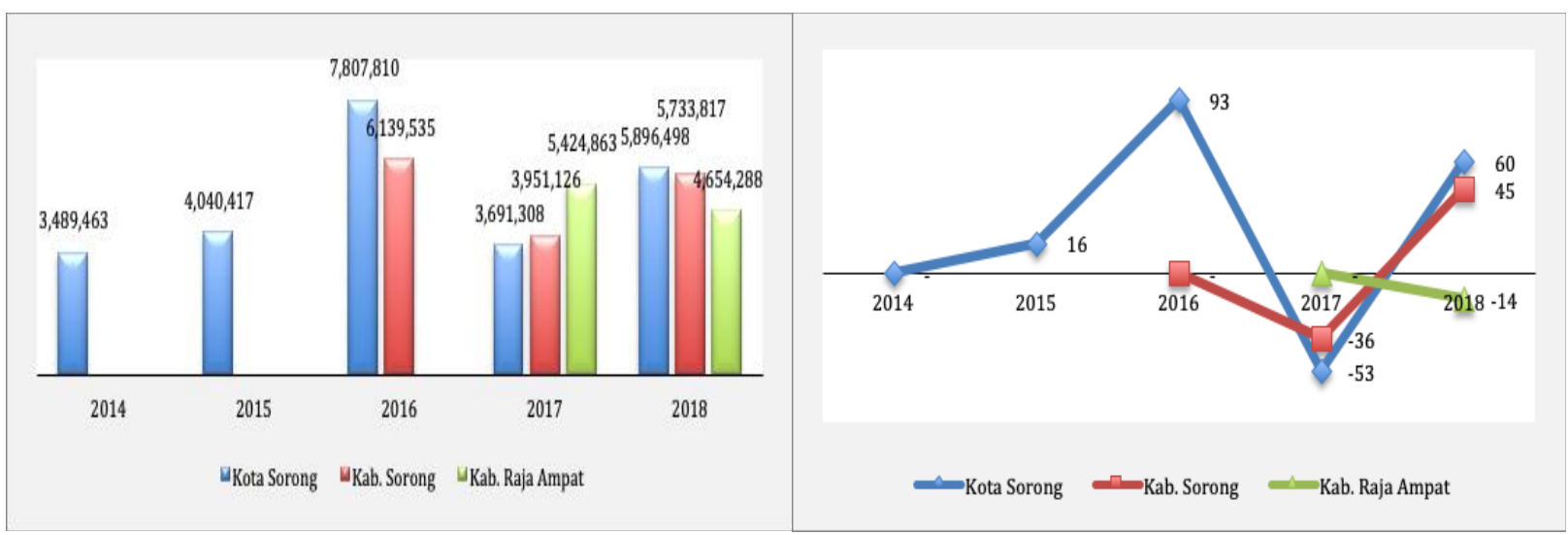

Sumber: APBD Kota Sorong, Kab. Sorong \& Kab. Raja Ampat, 2014 - 2018 (Data diolah)

Gambar 4. Total dan Pertumbuhan Pendapatan Perkapita, 2014 - 2018 
Pertumbuhan pendapatan perkapita masingmasing Kabupaten Kota berfluktuasi. Pendapatan perkapita Kota Sorong cenderung meningkat hingga Rp7,807,810 pada tahun 2016, walaupun pada tahun berikutnya mengalami penurunan, sehingga cenderung berfluktuasi. Fluktuasi tersebut dikarenakan adanya penurunan pendapatan daerah. Hal yang sama juga terdapat pada pendapatan perkapita Kabupaten Sorong yang menurun pada tahun 2017 yakni sebesar 36 persen yang kemudian meningkat sebesar 45 persen. Sedangkan untuk Kabupaten Raja Ampat menurun sebesar 14 persen.

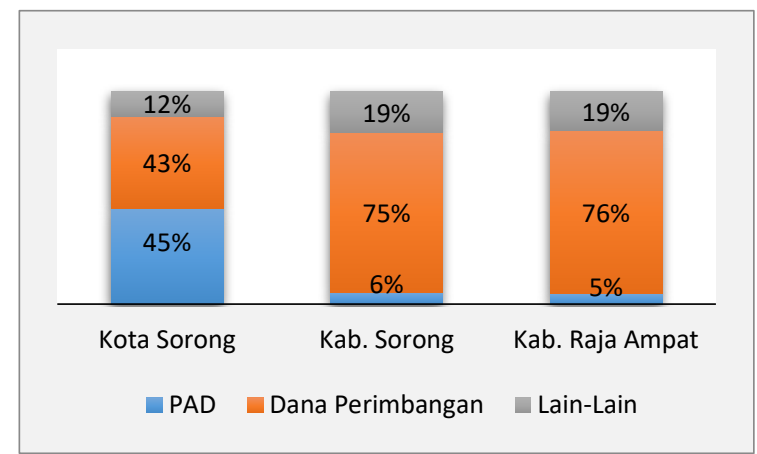

Sumber: APBD Kota Sorong, 2014 - 2018 (Data diolah)

Gambar 5. Proporsi Pendapatan Daerah Rill Terhadap Total Pendapatan Daerah, 2014 - 2018

Pendapatan daerah riil Kabupaten Sorong dan Kabupaten Raja Ampat didominasi oleh pendapatan yang berasal dari Dana Perimbangan, yakni sebesar 75 dan 76 persen. Sedangkan untuk Kota Sorong, pendapatan daerah rill didominasi oleh PAD. Walaupun demikian kontribusi yang berasal dari dana perimbangan juga cukup memberikan kontribusi yang besar. PAD yang bersumber dari pajak daerah, retribusi daerah, hasil pengelolaan kekayaan daerah yang dipisahkan dan lain-lain PAD yang sah sebesar 45 persen, sementara dana perimbangan yang bersumber dari DAU, DAK dan DBH sebesar 43 persen dan lain-lain sebesar 12 persen.

Komposisi PAD Kota Sorong didominasi oleh Pajak Daerah. Pajak daerah Kota Sorong mengalami penurunan pada tahun 2016, sebaliknya pada tahun 2018 mengalami peningkatan yang cukup tingi, dari Rp39 Milliar menjadi Rp1,079 Milliar. Dapat dilihat bahwa komposisi pajak daerah terhadap PAD pada tahun tersebut mendominasi dengan kontribusi sebesar 76.73 persen, diikuti dengan lain-lain pendapatan asli daerah yang sah sebesar 22.63 persen. Dengan tingginya kontribusi pajak daerah terhadap PAD Kota Sorong menunjukkan bahwa banyak komponen-komponen penerimaan yang bersumber dari berbagai jenis pajak yang dimaksimalkan dan dikelola dengan baik.

Kontribusi pajak dearah di Kota Sorong dari tahun 2014 sampai dengan 2018 mengalami peningkatan, dimana pada tahun 2014 sebesar Rp 26 Milliar meningkat menjadi Rp1,079 Milliar. Perolehan porsi pajak yang cukup tinggi ini disebabkan karena banyak sumber pajak daerah telah memberikan kontribusi terhadap penerimaan pajak daerah, terutama pada komponen pajak dearah bumi dan bangunan pedesaan dan perkotaan yang memberikan kontribusi yang cukup besar terhadap pajak daerah pada tahun 2018, yakni sebesar 89.15 persen. Sedangkan untuk Kabupaten Sorong kontribusi yang cukup besar terhadap pajak daerah yakni sebesar 40.44 persen adalah komponen Bea Perolehan atas Hak Tanah dan Bangunan. Untuk Kabupaten Raja Ampat di dominasi oleh komponen Bahan Galian Golongan C yakni sebesar 45.98 persen.

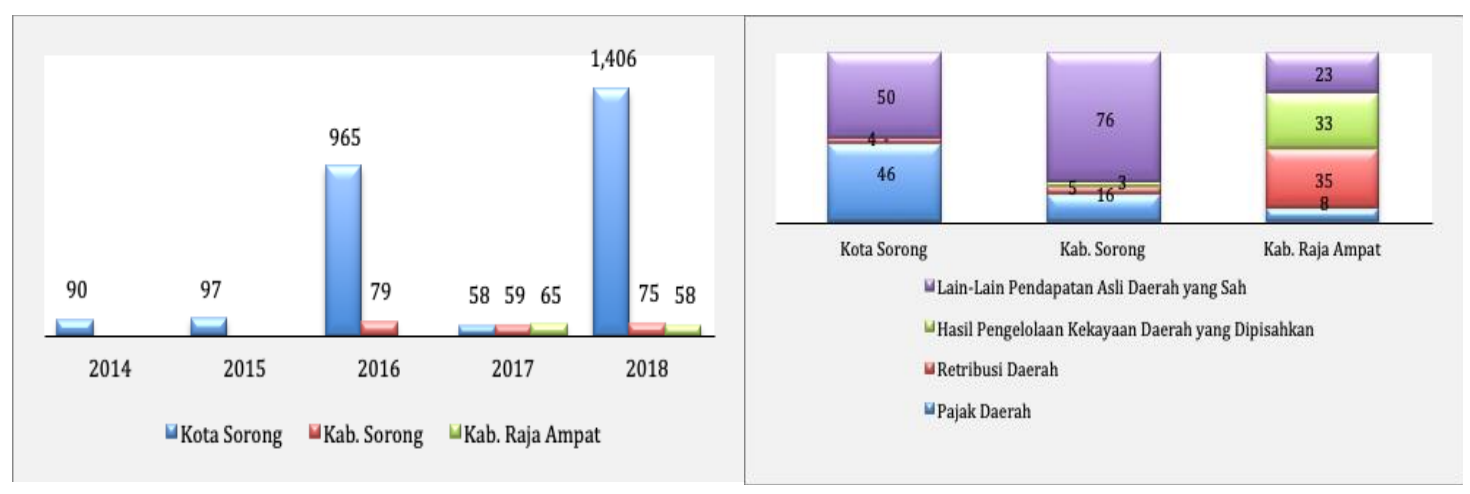

Sumber: APBD Kota Sorong, Kab. Sorong \& Kab. Raja Ampat, 2014 - 2018 (Data diolah)

Gambar 6. Pedapatan Asli Daerah dan Proporsi PAD, 2014 - 2018 

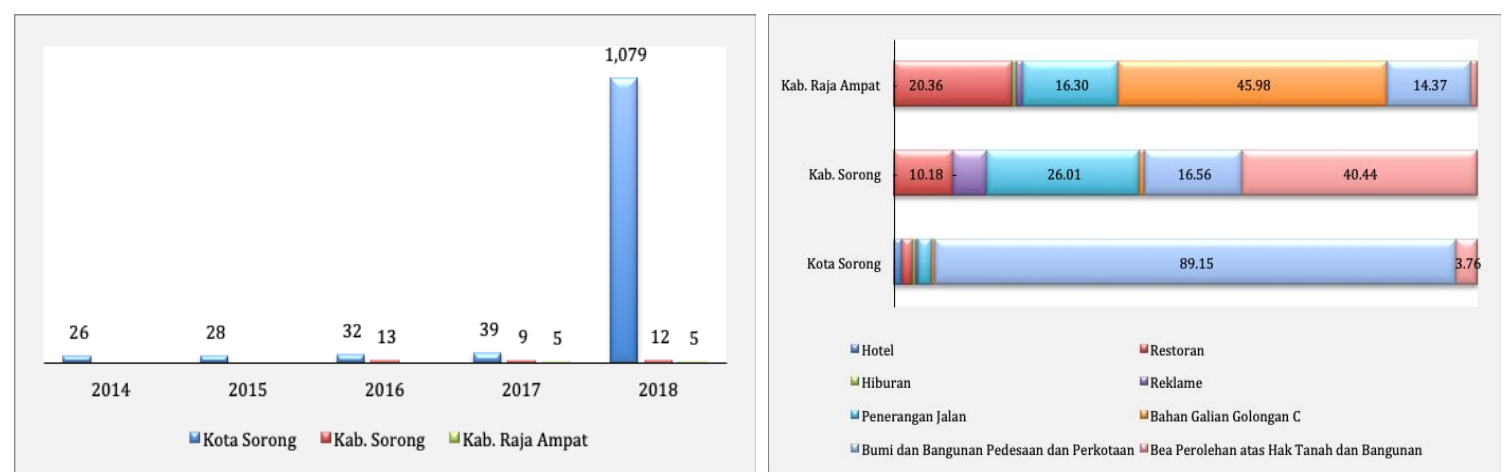

Sumber: APBD Kota Sorong, Kab. Sorong \& Kab. Raja Ampat, 2014 - 2018 (Data diolah)

Gambar 7. Pajak Daerah dan Proporsi Pajak Daerah, 2014 - 2018

Proporsi Retribusi Daerah pada masing-masing Kabupaten Kota berbeda. Dimana retribusi daerah Kota Sorong didominasi oleh perijinan dan retribusi jasa umum yakni sebesar 51 dan 42 persen. Sedangkan untuk Kabupaten Sorong Retrubusi Daerah didominasi oleh Retribusi Jasa Umum yakni sebesar 70 persen. Untuk Kabupaten Raja Ampat didominasi oleh Retribusi Perizinan Tertentu yakni sebesar 57 persen yang diikuti dengan Retribusi Jasa usaha sebesar 32 persen.

Perolehan pendapatan daerah yang bersumber dari dana perimbangan secara nominal mengalami peningkatan pada tahun 2014 sampai dengan tahun 2017, namun pada tahun berikutnya mengalami penurunan yang cukup signifikan. Secara proporsional sumber dana terbesar dari dana perimbangan berasal dari Dana Alokasi Umum (DAU) untuk masing-masing Kabupaten Kota, dimana Kota Sorong sebesar 73 persen, Kabupaten Sorong sebesar 54 persen dan Kabupaten Raja Ampat sebesar 46 persen.

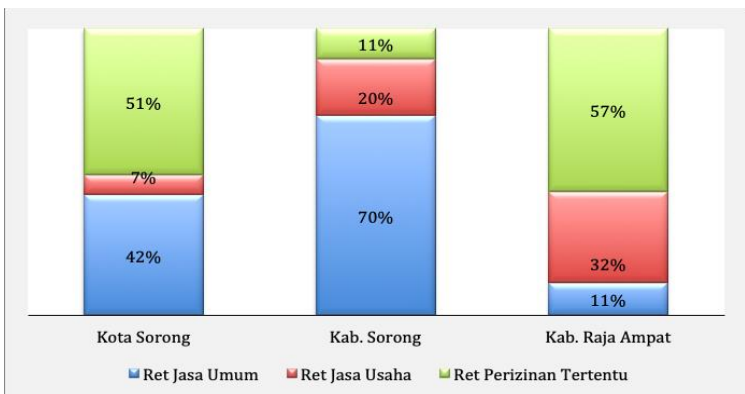

Sumber: APBD Kota Sorong, Kab. Sorong \& Kab. Raja Ampat, 2014 - 2018 (Data diolah)

Gambar 8. Proporsi Retribusi Daerah, 2014 - 2018

Proporsi Dana Bagi Hasil Pajak untuk masingmasing Kabupaten Kota didominasi oleh Dana Bagi Hasil pajak. Dimana untuk Kota Sorong sebesar 73 persen, Kabupaten Sorong sebesar 72 persen dan Kabupaten Raja Ampat sebesar 68 persen.

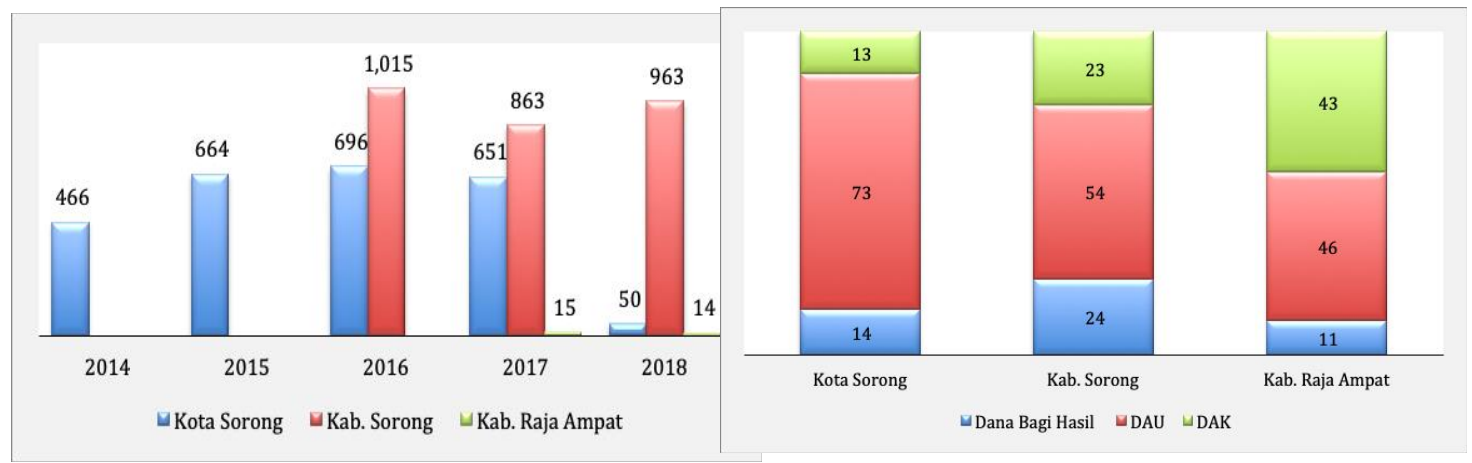

Sumber: APBD Kota Sorong, Kab. Sorong \& Kab. Raja Ampat, 2014 - 2018 (Data diolah)

Gambar 9. Perkembangan dan Proporsi Dana Perimbangan Rill, 2014 - 2018 


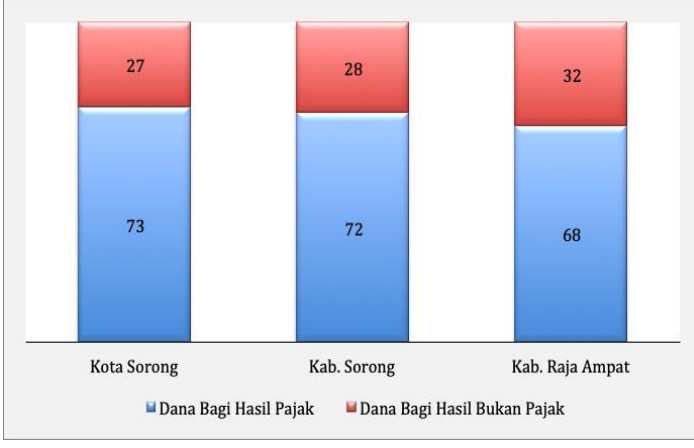

Sumber: APBD Kota Sorong, Kab. Sorong \& Kab. Raja Ampat, 2014 - 2018 (Data diolah)

Gambar 10. Proporsi Dana Bagi Hasil Pajak dan Bukan Pajak, 2014 - 2018

APBD Kota Sorong dan Kabuapten Sorong lebih dominan mencapai surplus daripada mengalami defisit. Pembiayaan surplus dicapai pada tahun 2015 - 2018, dan mengalami defisit pada tahun 2014. Surplus pendapatan tertinggi terjadi pada tahun 2016. Pembiayaan surplus dicapai tidak semata-mata sebagai sebuah kebijakan keuangan daerah, tetapi karena daya serap anggaran oleh pemerintah daerah yang rendah. Pada periode defisit, pembiayaan belanja daerah menggunakan sisa lebih perhitungan tahun lalu (siLPa). Adanya surplus yang besar menunjukkan mekanisme perencanaan penganggaran yang masih perlu dibenahi sehingga surplus tidak melebihi 6 persen sesuai dengan standar pengelolaan keuangan daerah.

Pendapatan rill Kota Sorong, Kabupaten Sorong dan Kabupaten Raja Ampat cenderung berfluktuasi selama kurun waktu $2014-2018$. Adanya penurunan pada tahun 2017 itu disebabkan karena menurunnya porsi Pendapatan Asli Daerah. Hal ini dikarenakan pos Hasil Pengelolaan Kekayaan Daerah yang Dipisahkan mengalami penurunan. Walaupun demikian PAD tetap memberikan kontribusi yang cukup besar terhadap pendapatan rill Kota Sorong selama lima tahun terakhir, diikuti juga dengan dana perimbangan. Untuk Kabupaten Sorong, dana perimbangan juga memberikan kontribusi yang cukup besar terhadap pendapatan rill Kabupaten Sorong selama tiga tahun terakhir.

Struktur pendapatan daerah pada Kabupaten Sorong dan Kabupaten Raja Ampat terutama terkait dengan kontribusi pajak daerah masih berfluktuasi sepanjang tahun dan cukup rendah. Kondisi ini perlu dilakukan penanganan yang lebih optimal melalui penyiapan sumberdaya manusia terkait penanganan tersebut dengan ketersediaan dukungan dalam bentuk fasilitas penunjang bagi petugas agar dapat dengan optimal melakukan fungsinya melalui pemungutan pajak. Sedangkan untuk Kota Sorong sudah cukup baik yang ditunjukkan dengan kontribusi pajak daerah terhadap PAD Kota Sorong yang cukup tinggi hal ini menunjukkan bahwa banyak komponenkomponen penerimaan yang bersumber dari berbagai jenis pajak yang telah dimaksimalkan dan dikelola dengan baik.

Sumber: APBD Kota Sorong, Kab. Sorong \& Kab.

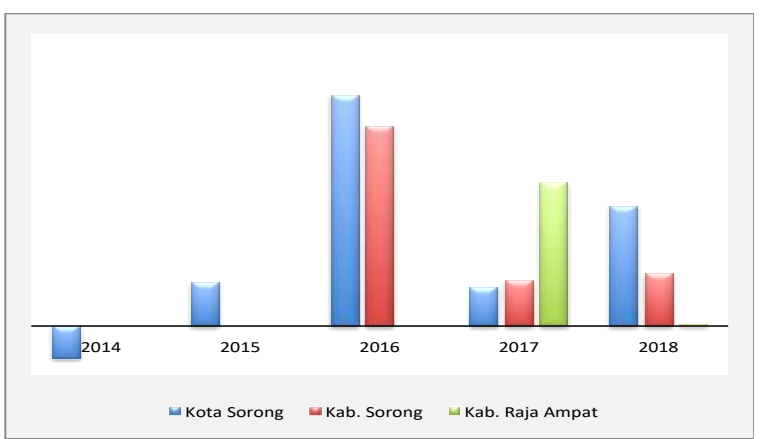

Raja Ampat, 2014 - 2018 (Data diolah)

Gambar 11. Perkembangan Surpus dan Defisit APBD, 2014 - 2018

Keberhasilan KEK di Negara India dan Cina terhadap pembangunan ekonomi ditandai dengan kegiatan investasi yang meningkat. Kondisi serupa terjadi di Provinsi Sulawesi Utara yang telah menarik investor sehingga mendorong pertumbuhan ekonomi yang ditandai dengan meningkatnya nilai tambah dari sektor sektor potensial. Nilai tambah yang dihasilkan tercermin dari perolehan pendapatan rill pada setiap wilayah KEK. Pendapatan rill pada KEK Sorong tercermin pada capaian Kota Sorong, Kabupaten Raja Ampat dan Kabupaten Sorong. Selama 5 tahun terakhir mebgalami pertumbuhan walaupun didominasi oleh Kota Sorong. Potensi pertumbuhan Kota Sorong sebagai sentral bisnis akan mendorong peningkatan output sektor sektor lainnya yang berada di Kabupaten Raja Ampat maupun Kabupaten Sorong, terlebih terjadinya peningkatan permintaan sektor sektor yang potensial yang berada pada 3 zona KEK Sorong.

Sumber pendapatan daerah pada KEK lebih didominasi oleh dana perimbangan kecuali kota Sorong yang memiliki porsi PAD mencapai 45 persen. Capaian yang tinggi tersebut disebabkan oleh aktifitas sektor jasa yang mendominasi dibandingkan dengan kabupaten Raja Ampan dan Sorong yang lebih di dominasi oleh sektor pertanian. Artinya daya saing sekrtor jasa Kota 
Sorong lebih tinggi dibandingkan Kabupaten Raja Ampat dan Kabupaten Sorong hal ini sejalan dengan ungkapan Glinskiy et al. (2020) tentang spesifikasi dayasaing suatu daerah yang lebih spesifik.

Pendapatan perkapita yang didominasi oleh Kota Sorong sejak tahun 2014 namun pada tahun 2017 pendapartan perkapita Kabupaten Raja Ampat dan Kabupaten Sorong, mampu melebihinya ini menunjukkan bahwa sektor potensial pada kedua kabupaten tersebut telah memberikan kontribusi yang cukup berarti bagi peningkatan pendapatan masyarakat sehingga konsumsi masyarakat dan kesejahteraan masyarakat meningkat, hal ini sejalan dengan yang diungkapkan dalam konsep Harod dan Domar. Porsi pendapatan daerah riil terhadap total pendapatan yang didominasi oleh Kota Sorong menunjukkan bahwa aktivitas ekonominya lebih produktif dibandingkan dengan kedua kabupaten lainnnya yang dapat dilihat dari perolehan pajak dan retribusi daerah yang lebih mendominasi.

Pengalaman empiris menunjukkan bahwa lokasi industri mempengaruhi aktifitas masyarakat dalam kehidupan sehari-hari sehingga terdapat beberapa pilihan bagi masyarakat yang ingin bekerja pada berbagai sektor usaha. Pilihan tersebut mempengaruhi kebiasaan hidup untuk beradaptasi dengan perkembangan kawasan industri tersebut (Webber, 2009). Terserapnya penduduk lokal dalam berbagai sektor usaha memberikan dampak terhadap perolehan pendapatan yang ditunjukkan oleh pendapatan perkapita yang mengalami peningkatan secara komulatif walaupun didominasi oleh Kota Sorong.

Aktivitas ekonomi selama 5 tahun terakhir pada kawasan KEK tersebut yang mulai nampak sejak tahun 2016 secara akumulatif perolehan PAD terbesar terjadi di Kota Sorong hingga mencapai $45 \%$ dari total pendapatan yang diterima di bandingkan dengan Kabupaten Raja Ampat dan Kabupaten Sorong yang hanya mencapai 5 persen dan 6 persen, yang mengakibatkan ketergantungan Dana Perimbangan untuk kedua Kabupaten tersebut cukup

Sejak beroperasi tanggal 11 Oktober 2019 Investor yang sudah masuk antara lain adalah PT Semen Gresik, PT Henrison Inti Putra, PT Bumi Sarana Utama (Kalla Group) juga terdapata beberapa investor lainnya seperti PT Gag Nikel untuk pembangunan smelter nikel dan PT Power Gen untuk pembangunan Pembangkit Listrik
Tenaga Mesin Gas sebesar 20 MW. Peran dari investor tersebut akan dapat memacu pertumbuhan ekonomi Kota Sorong sehingga akan mendorong perolehan pendapatan masyarakat karena adanya peningkatan nilai tambah dari fakor produksi tenaga kerja yang terserap pada masing masing perusahaan yang melakukan investasi di KEK Sorong.

Meningkatnya perolehan pendapatan daerah dalam bentuk pajak dan retribusi daerah sebagai salahbsatu indikator kemajuan ekonomi dari suatu wilayah seperti yang ditunjukkan dalam tabel 6 dan tabel 7 yang didominasi oleh Kota Sorong. Perolehan PAD telah mencapai 5,01 persen dari total pendapatan, nilainya jauh lebih tinggi dari Kabupaten Sorong dan Kabupaten Raja Ampat yang hanya mencapai 1,5 persen dan 1,8 persen. Dengan adanya KEK Sorong ini telah memacu perolehan pendapatan daerah Kota Sorong, Kabupaten Sorong dan Kabupaten Raja Ampat.

Tingginya kontribusi pajak daerah khususnya di Kota Sorong memberikan implikasi bahwa pengembangan KEK ini sangat tergantun pada perilaku spasial masyarakat baik penduduk, pihak swasta maupun pihak pemerintah daerah. Perilaku tersebut terintegrasi dalam suatu mekanisme kelembagaan yang masing-masing cenderung berperilaku menurut tujuan masingmasing. Penduduk yang terakses dalam faktor produksi tenaga kerja akan menempatkan kesejahteraan keluarga sebagai tujuan utama, pihak swasta akan menempatkan profit usaha sebagai tujuan utama dan pemerintah berupaya untuk meningkatkan kesejahteraan masyarakat secara umum.

Nilai produksi yang dihasilkan dari nilai tambah sektor ekonomi pada KEK Sorong merupakan proses produksi yang terjadi dalam kurun waktu satu tahun dengan kontribusi dari faktor produksi yang tersedia. Peran pemerintah yang hanya menyediakan barang dan jasa membutuhkan kesinergian kontribusi baik dari penduduk maupun pihak swasta. Kesinergian ini akan menghasilkan output yang optimal sehingga memberikan kontribusi pada PDRB pada KEK Sorong.

Pada tahap permulaan KEK menunjukkan bahwa Kota Sorong lebih medominasi perolehan pendapatan baik pada masing-masing sektor usaha maupun terhadap pendapatan perkapita masyarakat. Dengan berjalannya waktu maka Kabupaten lainnnya seperti Kabupaten Raja 
Ampat dan Kabupaten Sorong yang bersinggungan ekonomi dengan Kota Sorong memperoleh manfaat atas pemanfaatan faktor produksi.

\section{KESIMPULAN}

Berkembangnya KEK Sorong berimplikasi pada kepastian dari investor yang telah memulai kegiatan investasinya sehingga telah mendorong perolehan pendapatan baik yang diterima oleh pihak penduduk, pihak swasta maupun pemerintah. Dapat dilihat bahwa aktivitas ekonomi selama 5 tahun terakhir yang mulai nampak sejak tahun 2016 secara akumulatif perolehan PAD terbesar terjadi di Kota di bandingkan dengan Kabupaten Raja Ampat dan Kabupaten Sorong. PAD yang bersumber dari aktifitas ekonomi ini didominasi oleh sektor jasa dibandingkan Kabupaten Raja Ampat dan Kabupaten Sorong didominasi oleh sektor Pertanian.

Perolehan pendapatan perkapita Kota Sorong yang lebih dominan menunjukan bahwa nilai tambah sektor jasa lebih kompetitif dibandingkan dengan sektor lainnnya. Berkembangnya Kota Sosong sebagai sentral KEK telah mendorong berkembangnya Kabupaten Sorong dan Kabupaten Raja Ampat sehingga yang perlu di perhatikan bahwa kedua Kabupaten tersebut harus dapat mendorong faktor produksi yang menjadi input pada pengembangan Kota Sorong.

Faktor penting yang harus diperhatikan dalam pengembangan KEK Sorong adalah pengkatan kapasistas penduduk sebagai faktor produksi dan pengembangan home industri masyarakat yang memanfaatkan bahan baku lokal dalam menunjang sektor sektor unggulan yang berada pada masing-masing wilayah pada KEK Sorong sehingga dapat memacu peningkatan pendapatan masyarakat secara umum.

\section{DAFTAR PUSTAKA}

Aisya. 2006. Disparitasm Konservasi dan Determinan Produktivitas Tenaga Kerja. http://media.peneliti.com>publications.

BPS Kabupaten Manokwari. 2014. Kabupaten Manokwari Dalam Angka Tahun 2014.

BPS Kabupaten Manokwari. 2015. Kabupaten Manokwari Dalam Angka tahun 2014.

BPS kabupaten manokwari. 2015. Tenaga Kerja Kabupaten Manokwari Tahun 2015.
Kaufman dan Hotchkiss. 1999 The Economic Labor markets. USA: Georgia State University.

Mahendra. 2014. "Analisis Pengaruh Pendidikan, Upah, Jenis Kelamin, Usia Pengalaman Kerja Terhadap Produktivitas Tenaga Kerja”, dikota Semarang, Universitas Diponegoro.

Moelyono, 1997. Pengangguran tenaga kerja terdidik. Bumi Aksara, Jakarta.

Moelyono, Supriadi, 2006. Ekonomi sumber Daya Manusia. Jakarta: PT Raja Grafindo Persada.

Sanusi. Anwar 2011. Metode Penelitian, Jakarta.

Setiawan. 2010, "Analisis Penyerapan Tenaga Kerja Pada Sektor Usaha Kecil Dan Menegah (UKM) di Kota Semarang”.

Sinungan, Muchdarsyah 2005. Produktivitas: apa dan bagaimana. Edisi kedua. Bumi aksara.

Sugiono, 2012. Metode Penelitian Kuantitatif Kualitaif dan R\&D Bandung: Alfabeta.

Supranto, J. 1997. Statistik teori dan Aplikasi. Jilid 1 Edisi ke Lima, Jakarta.

Wardani, Kusuma, Dewi. 2009. Riset Sumber Daya manusia, Jakarta: PT. Gramedia Pustaka Utama. 